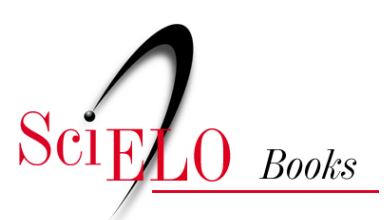

\title{
Reflexões \\ A Ciência no banco de reservas
}

\author{
Nelson De Luca Pretto
}

PRETTO, N.D.L. A Ciência no banco de reservas. In: Educações, culturas e hackers: escritos e reflexões [online]. Salvador: EDUFBA, 2017, pp. 161-163. ISBN: 978-85-232-2019-8.

https://doi.org/10.7476/9788523220198.0040.

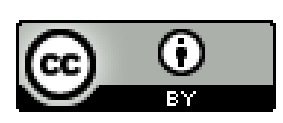

All the contents of this work, except where otherwise noted, is licensed under a Creative Commons Attribution $\underline{4.0 \text { International license. }}$

Todo o conteúdo deste trabalho, exceto quando houver ressalva, é publicado sob a licença Creative Commons Atribição 4.0.

Todo el contenido de esta obra, excepto donde se indique lo contrario, está bajo licencia de la licencia $\underline{\text { Creative }}$ Commons Reconocimento 4.0. 
A Amazônia, sem fronteiras, está aberta, através do Acre de Chico Mendes e de tantos outros ativistas que lutam pelas questões ambientais do planeta, para uma ampla discussão sobre a ciência brasileira. Até domingo próximo, estaremos aqui animados com essa verdadeira festa do conhecimento e dos saberes.

Publicado na revista online Terra Magazine e, em uma versão reduzida, no jornal Correio*, Salvador, em 22 de julho de 2014.

\section{A Ciência no banco de reservas}

Com muito alarde, foi anunciado que na abertura da Copa do Mundo haveria um efeito-surpresa ligado ao desenvolvimento da ciência brasileira. Por alguma razão, ainda não explicada, a cena do chute de um paraplégico, vestindo um exoesqueleto, foi praticamente reduzida a poucos segundos daquela sofrível cerimônia. No mesmo dia, começaram a circular na mídia críticas ao evento e, junto com elas, ao experimento que seria uma forma de popularizar o desenvolvimento científico do país. Em artigo imediatamente publicado em $O$ Globo, o neurocientista Roberto Lent, diretor do Instituto de Biociências da UFRJ, vencedor do prêmio Faz a Diferença 2013 e um dos fundadores e presidente do Conselho do Instituto Ciência Hoje da SBPC, foi categórico ao afirmar que o show do exoesqueleto "viola um princípio ético básico da divulgação científica", que é o de só se divulgar algo após a sua comprovação e publicação em revistas especializadas. Nada disso foi feito e, mais ainda, segundo Lent, o financiamento recebido da Financiadora de Estudos e Projetos (FINEP) para essas pesquisas foram da ordem de $\mathrm{R} \$ 33$ milhões, soma altíssima se comparada, por exemplo, com 
o edital lançado agora em junho para a criação dos Institutos Nacionais de Ciência e Tecnologia, que destinará, pelas contas de Lent, "algo em torno de $\mathrm{R} \$ 1$ milhão” por projeto. Mais longe está do teto de R\$120 mil para receber apoio do CNPq em edital universal, cujo prazo para submissão foi recentemente encerrado.

Estes são apenas alguns exemplos que nos levam a pensar mais a fundo sobre o financiamento da pesquisa no país. A Sociedade Brasileira para o Progresso da Ciência (SBPC) tem sido uma árdua lutadora na defesa de mais recursos para Ciência e Tecnologia (C\&T) e, principalmente, por maior transparência na aplicação desses recursos, vindos de fontes distintas, como mencionou o seu vice-presidente, Enio Candotti. São recursos dos fundos setoriais, dos futuros royalties do petróleo para educação e saúde, recursos recolhidos pela lei de informática (Enio: "5\% do faturamento para P\&D somam mais de quatro bilhões. Só na SUFRAMA, na Amazônia, corresponderam em 2013 a 1,3 bilhões de reais!”), são verbas do fundo de telecomunicações, nesse último com o Fundo da Universalização do Serviços de Telecomunicações (FUST), instituído durante o processo de privatização da telefonia brasileira por meio Lei Geral da Telecomunicações (LGT), cujo objetivo era universalizar as telecomunicações no país, já tendo arrecadado mais de 12 bilhões que, no entanto, estão servindo apenas para alimentar o superávit primário brasileiro.

A SBPC e os pesquisadores brasileiros têm lutado para a criação de leis que vinculem a aplicação desses recursos em C\&T, educação e saúde e, com isso, evitar o desperdício dessas verbas em outras áreas. Está em tramitação uma proposta de extinção da Comissão de Ciência e Tecnologia (CCT) do Senado Federal, o que certamente diminuirá mais ainda as possibilidades de discussão sobre o uso desses recursos. Só para se ter uma ideia, essa comissão, ao longo de sua história, já votou mais de quatro mil proposições e realizou mais de 300 reuniões. Mas isso não basta. É preciso um rígido sistema de monitoramento e avaliação da distribuição e uso desses recursos para que possamos efetivamente ter melhores resultados na sua utilização. Na esfera estadual, precisamos também desses mecanismos para que seja possível um maior controle das ações das Fundações de Apoio à Pesquisa e dos investimentos em $\mathrm{C} \& \mathrm{~T}$ dos governos estaduais. Estamos vivendo em todo o país, e imagino que no Acre não deva ser dife- 
rente, um processo de burocratização e de contingenciamento financeiro e, o pior, com uma enorme dificuldade na liberação dos recursos aprovados, o que praticamente desestimula a própria pesquisa.

A SBPC é uma ferrenha lutadora pela criação das Fundações de Apoio à Pesquisa e Inovação e, com a 66a reunião anual que acontecerá em Rio Branco, agora em julho [2014], estaremos mais atentos a isso. Com as eleições para presidente e governadores que se aproximam, esta reunião anual será um importante espaço para que pesquisadores da região amazônica possam cobrar propostas concretas para o desenvolvimento da ciência e tecnologia em todo o país e, principalmente, na região, com uma séria política de divulgação científica.

Publicado no jornal A Tarde, Salvador, em 19 de junho de 2014.

\section{Jovens cientistas criadores de cultura}

"Física também é cultura" foi o título da tese de doutorado do meu mestre, professor João Zanetic, do Instituto de Física da USP, por volta de 1990. Aqui pela Bahia, outra querida referência acadêmica, o saudoso professor Felippe Serpa, também insistia que o ensino das ciências tinha que superar o "conteudismo" das fórmulas prontas e avançar para uma formação científica ampla da juventude. Além disso, pensava na não separação da ciência com a cultura e ia mais longe: defendia sempre que ambas tinham que ser vistas no plural, ou seja, as ciências e as culturas tinham que estar sempre articuladas.

Essas são questões que me vêm à mente, principalmente quando tanto se fala na mídia sobre os últimos resultados do Programa Internacio- 